Article

\title{
Degradation of Sulfamethoxazole Using Iron-Doped Titania and Simulated Solar Radiation
}

\author{
Athanasios Tsiampalis ${ }^{1}$, Zacharias Frontistis ${ }^{2} \mathbb{D}^{\mathbb{D}}$, Vassilios Binas ${ }^{3,4}{ }^{\mathbb{D}}$, George Kiriakidis ${ }^{3,4}$ and \\ Dionissios Mantzavinos $1, *$ (D) \\ 1 Department of Chemical Engineering, University of Patras, Caratheodory 1, University Campus, \\ 26504 GR Patras, Greece \\ 2 Department of Chemical Engineering, University of Western Macedonia, GR-50100 Kozani, Greece \\ 3 Institute of Electronic Structure and Laser (IESL), FORTH, P.O. Box 1527, Vasilika Vouton, \\ 71110 GR Heraklion, Greece \\ 4 Quantum Complexity \& Nanotechnology Center (QCN), Department of Physics, University of Crete, \\ P.O. Box 2208, 71110 GR Heraklion, Greece \\ * Correspondence: mantzavinos@chemeng.upatras.gr; Tel.: +30-2610996136
}

Received: 5 June 2019; Accepted: 17 July 2019; Published: 19 July 2019

\begin{abstract}
This work examined the photocatalytic destruction of sulfamethoxazole (SMX), a widely used antibiotic, under simulated solar radiation using iron-doped titanium dioxide as the photocatalyst. Amongst the various iron/titania ratios examined (in the range $0 \%-2 \%$ ), the catalyst at $0.04 \% \mathrm{Fe} / \mathrm{TiO}_{2}$ molar ratio exhibited the highest photocatalytic efficiency. The reaction rate followed pseudo-first-order kinetics, where the apparent kinetic constant was reduced as the initial concentration of SMX or humic acid increased. The photodecomposition of SMX was favored in natural $\mathrm{pH}$ but retarded at alkaline conditions. Unexpectedly, the presence of bicarbonates (in the range of $0.125-2 \mathrm{~g} / \mathrm{L}$ ) improved the removal of SMX, however, experiments conducted in real environmental matrices showed that process efficiency decreased as the complexity of the water matrix increased. The presence of sodium persulfate as an electron acceptor enhanced the reaction rate. However, only a small synergy was observed between the two individual processes. On the contrary, the addition of tert-butanol, a well-known hydroxyl radical scavenger, hindered the reaction, indicating the significant contribution of these radicals to the photocatalytic degradation of SMX. The photocatalyst retained half of its initial activity after five successive experiments.
\end{abstract}

Keywords: emerging micro-contaminants; kinetics; operating conditions; photocatalysis; water matrices

\section{Introduction}

The discovery of penicillin in 1928 by Fleming was a focal point for improving human health and increasing life expectancy [1]. Since then, the use of antibiotics has treated millions of infections that could prove fatal. Due to the impressive results of penicillin, a large part of the scientific community was involved in the production of new synthetic antibiotics that could further improve the quality of human life [2].

Unfortunately, the production of new drugs has been accompanied by their misuse, resulting in a large number of pharmaceutical compounds being detected in environmental samples. Indeed, many studies indicate the detection of pharmaceuticals in both wastewater treatment plants, as well as surface and groundwater [3-6]. For example, sulfamethoxazole (SMX), a widely used sulfonamide antibiotic, has been detected at concentrations of up to $1.1 \mu \mathrm{g} / \mathrm{L}$ in surface water $[7,8]$ and up to $2.8 \mu \mathrm{g} / \mathrm{L}$ in wastewater treatment plants [9]. Moreover, antibiotics are one of the most dangerous groups that can disturb the ecological balance. Exposure to antibiotics may lead to an increase in microbial resistance to antibiotics, and thus a decrease in their efficacy [10]. 
To address this emerging issue, the scientific community turned to developing new advanced processes to remove persistent pollutants from waters and wastewaters [11]. For the removal of antibiotics like sulfamethoxazole and amoxicillin, a large number of technologies have been investigated, such as ozonation [12], electrolysis [13], wet peroxide oxidation [14], Fenton and Fenton-like reactions [15,16], sonocatalysis [17], $\mathrm{UV} / \mathrm{H}_{2} \mathrm{O}_{2}$ [18] and photocatalysis [19-22]. Amongst the various processes, photocatalysis seems to be the most interesting one since the possible use of solar energy can lead to an integrated green solution with a minimal energy footprint [23].

In recent years, there have been hundreds of publications dealing with different applications of photocatalysis, including amongst others, different sources of radiation, different types of reactors and the combination with other processes. A key factor to optimize process performance and therefore expand its usage to real-world applications is the photocatalyst and its properties [24]. Unfortunately, titanium dioxide, the most well-known and widely used catalyst, has two significant disadvantages, namely [25]: (i) Its relatively large energy gap that absorbs only in the ultraviolet part of solar radiation. Therefore, it requires artificial lighting, which significantly increases the cost of the process; and (ii) a large proportion of the photoproduced holes and electrons are recombined, thus reducing the production of active oxidizing species.

To overcome these handicaps, the scientific community has focused on two different aspects, namely [25,26]: (i) The synthesis of a new generation of materials that can absorb in the visible part of the solar spectrum, like $\mathrm{Ag}_{3} \mathrm{PO}_{4}, \mathrm{BiVO}_{4}$ and various composites with improved properties, and (ii) the modification of existing materials, like $\mathrm{TiO}_{2}$ with the use of either anions or cations in order to lower their gap energy and/or reduce the recombination rate of electrons and holes. This said, new materials that can function under visible irradiation suffer from either low stability, like silver phosphate [20] or low efficiency, like bismuth vanadate [27]. In this perspective, the modification of cheap and stable materials such as titanium dioxide is an interesting strategy. In a previous work from our group, we have demonstrated that the use of platinum-doped titanium dioxide can improve the photocatalytic degradation of endocrine disruptor bisphenol A under simulated solar irradiation. In another study, different precious metals $(\mathrm{Pt}, \mathrm{Ru}, \mathrm{Pd}, \mathrm{Rh}$ ) were employed to dope titanium dioxide; of these, a $0.5 \%$ $\mathrm{Rh} / \mathrm{TiO}_{2}$ sample showed increased activity for bisphenol A degradation in the presence of humic acid [28]. However, the relatively high cost of precious metals, as well as their limited availability, restrict real-world applications.

In a recent work, Venieri et al. [29] examined the use of different metals for the modification of titanium dioxide. They found that amongst iron, aluminum and chromium, iron-doped titania exhibited higher efficiency for the elimination of Staphylococcus aureus under artificial and natural sunlight. $\mathrm{Fe}^{3+}$ has attracted considerable attention due to its half-filled d-electron configuration (3d5), while the ionic radius of $\mathrm{Fe}^{3+}(0.064 \mathrm{~nm})$ is close to that of $\mathrm{Ti}^{4+}(0.068 \mathrm{~nm})$, thus implying that $\mathrm{Fe}^{3+}$ may be incorporated into the structure of the $\mathrm{TiO}_{2}$ lattice. In recent studies, iron-doped titania nanoparticles and thin films were synthesized, characterized and tested for the degradation of methylene blue [30], phenol [31] and nitrobenzene [32] in water under visible irradiation. In other studies [33], a low-cost and easy procedure was established to synthesize an iron-doped titania, a cauliflower-like photocatalyst for the degradation of azodyes in water.

As a continuation of the study of Venieri et al. [29], the scope of this work is to examine whether iron-doped titania (i.e., role of Fe doping on the phase transition, crystalline size, light absorption and band gap) can improve the photocatalytic degradation of emerging contaminants, like antibiotics, under simulated solar radiation; this is so since environmental samples contain, amongst others, organic matter, microorganisms, microcontaminants and persistent pollutants. Briefly, this work aims to contribute to an integrated assessment of the photocatalytic activity of iron-doped titanium dioxide. 


\section{Results and Discussion}

\subsection{Structural, Optical and Morphological Properties of Iron-Doped Materials}

X-ray diffraction (XRD) patterns of Fe-doped $\mathrm{TiO}_{2}$ samples are shown in Figure 1. Dopant concentrations of Fe varied from 0.04 to $2 \%$. Anatase signature peaks can be seen at $2 \theta$ values of 25.3, 37.6, 48.2, 53.9, 54.8, 62.7 and 75.2, which correspond to the (101), (004), (200), (105), (211), (204) and (215) planes, respectively. At the higher concentrations of $0.3 \%$ and $2 \%$, an additional peak at $2 \theta$ value of 27.4 is distinguished, which corresponds to the crystal plane (110) of the rutile phase. Powder XRD patterns of all the catalysts do not show any diffraction peaks of iron or iron compounds, implying that there is a dispersion of metal ions on $\mathrm{TiO}_{2}$ accompanied by the replacement of $\mathrm{Ti}^{4+}$ ions from $\mathrm{Fe}^{3+}$ into the $\mathrm{TiO}_{2}$ lattice. The Scherrer formula was used to calculate the particle size of undoped and $\mathrm{Fe}$-doped $\mathrm{TiO}_{2}$ and it was found to be $40 \mathrm{~nm}$ and $\sim 30 \mathrm{~nm}$, respectively. Table 1 shows various particle characteristics. At low concentrations, the lattice parameters and cell volume decrease with increasing dopant concentration without phase transformation from anatase to rutile. The latter occurs at high concentrations $(0.3 \%$ and $2 \%)$ from 92 to 10 .

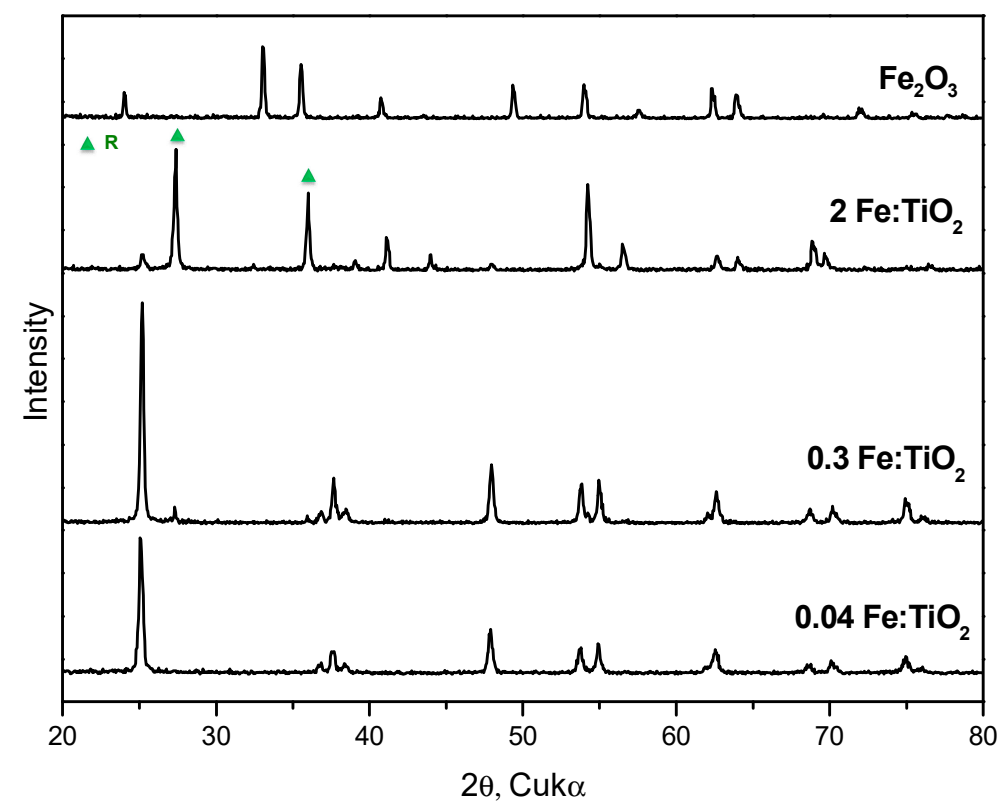

Figure 1. Effect of metal loading on structural characteristics of materials calcined at $973 \mathrm{~K}$ for $3 \mathrm{~h}$.

Table 1. Particle size, lattice parameters, cell volume, $\mathrm{f}_{\text {anatase }}$ values and energy band gap of undoped and $\mathrm{Fe}$ doped $\mathrm{TiO}_{2}$ materials. ${ }^{\text {a }}$ Sub band gaps.

\begin{tabular}{|c|c|c|c|c|c|c|}
\hline \multirow{2}{*}{$\begin{array}{c}\text { Fe Doping } \\
(\%)\end{array}$} & \multirow{2}{*}{$\begin{array}{l}\text { Particle Size } \\
\text { (nm) }\end{array}$} & \multicolumn{2}{|c|}{ Lattice Parameters (Å) } & \multirow{2}{*}{$\begin{array}{l}\text { Cell Volume } \\
\qquad\left(\AA^{3}\right)\end{array}$} & \multirow{2}{*}{$\mathbf{f}_{\text {anatase }}$} & \multirow{2}{*}{$\begin{array}{c}\text { Band Gap } \\
(\mathrm{eV})\end{array}$} \\
\hline & & $a=b$ & c & & & \\
\hline 0 & 40 & 3.786 & 9.518 & 136.416 & 100 & 3.2 \\
\hline 0.04 & 27 & 3.810 & 9.541 & 138.498 & 100 & 3 \\
\hline 0.3 & 33 & 3.796 & 9.547 & 137.569 & 92 & 2.85 \\
\hline 2 & 30 & - & - & - & 10 & $2.4-1.85^{\mathrm{a}}$ \\
\hline
\end{tabular}

Figure 2a depicts the absorption spectra of the undoped and doped samples, where a shift towards the visible light region $(400-800 \mathrm{~nm}$ ) occurs as the dopant concentration increases; it has been suggested that this visible light absorption may be due to (i) the formation of a $\mathrm{Fe}^{3+} / \mathrm{Fe}^{4+}$ dopant energy level within the band gap of $\mathrm{TiO}_{2}$, and (ii) the $\mathrm{d}-\mathrm{d}$ transition of $\mathrm{Fe}^{3+}(2 \mathrm{~T} 2 \mathrm{~g} \rightarrow 2 \mathrm{~A} 2 \mathrm{~g}, 2 \mathrm{~T} 1 \mathrm{~g})$ or the charge transfer transition between the interacting Fe ions via conduction band. The Kubelka-Munk spectra 
are shown in Figure $2 b$; the variation of the band gap energy with dopant concentration is evident and the exact values are given in Table 1.

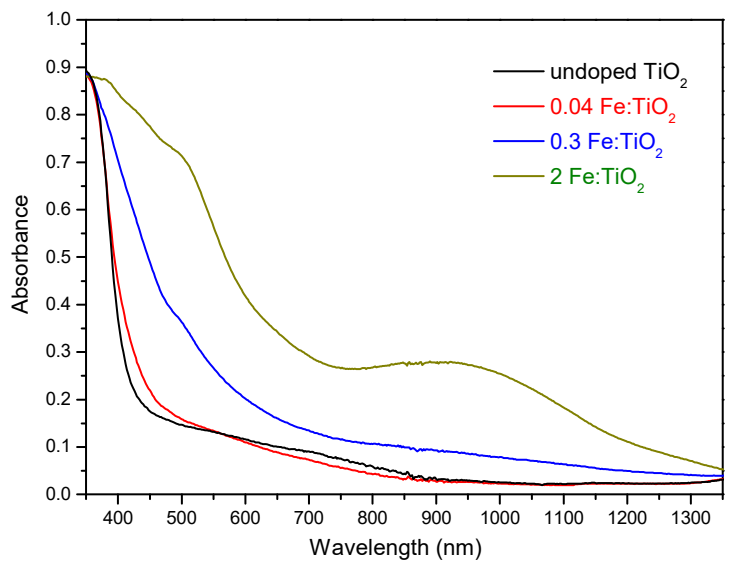

(a)

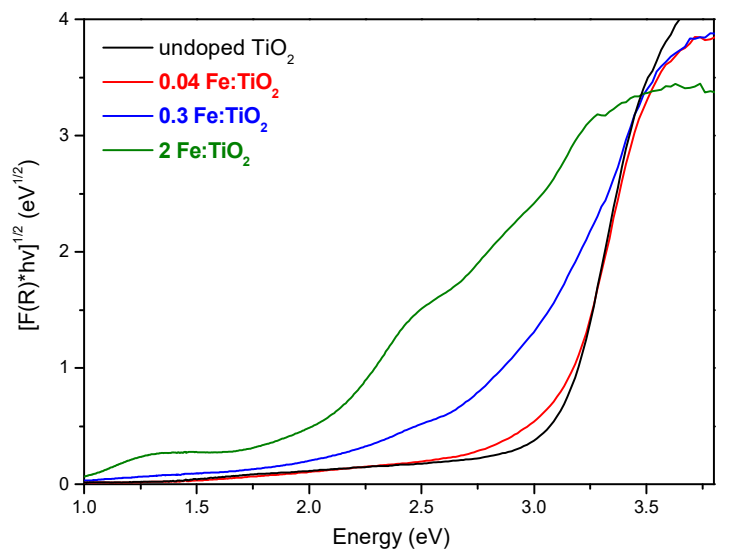

(b)

Figure 2. UV-Vis absorption (a) and Kubelka-Munk (b) spectra of undoped and doped samples.

SEM images of doped samples are shown in Figure 3. The diameter of spherical particles is within the range $0.1-40 \mu \mathrm{m}$, exhibiting a degree of agglomeration. The composition analysis of the $2 \%$ sample was carried out by the EDS technique and the pattern is also shown in Figure 3. Separate peaks of Ti, $\mathrm{Fe}$ and $\mathrm{O}$ appear, which confirms the successful doping of $\mathrm{Fe}$ in the $\mathrm{TiO}_{2}$.
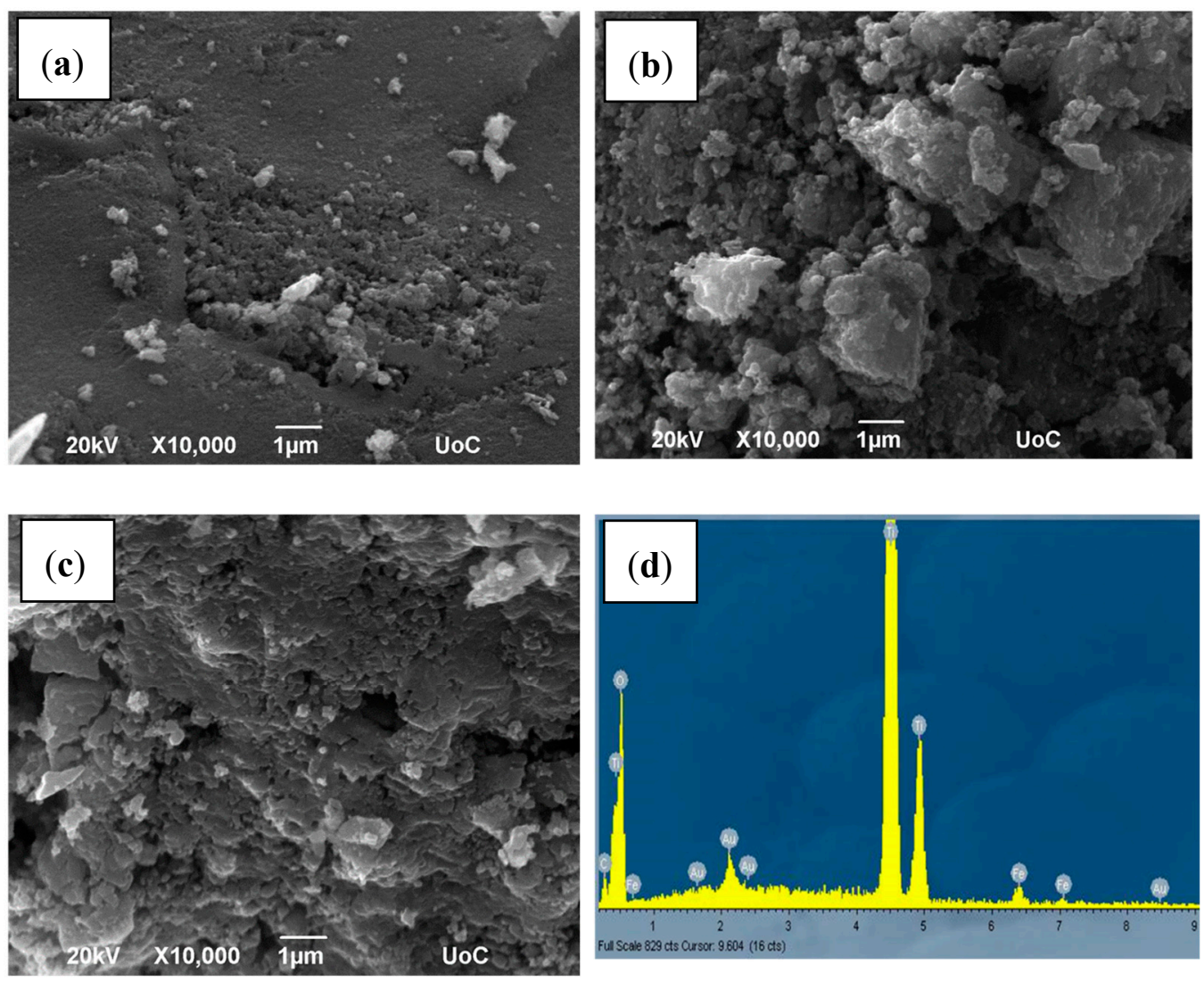

Figure 3. SEM images of doped samples ((a): $0.04 \%$; (b): $0.3 \%$; (c): $2 \%$ ) and EDS spectrum of the $2 \%$ sample (d). 


\subsection{Effect of Iron Doping Level}

In screening experiments, the effect of iron doping on SMX degradation in ultrapure water (UPW) was studied and the results are shown in Figure 4. It is evident that amongst the three concentrations of iron tested (i.e., $0.04 \%, 0.3 \%$, and $2 \%$ ), only the smallest one exhibits efficiency higher than the pristine, undoped titanium dioxide. Moreover, the beneficial role of photocatalysis is shown in Figure 5, where the extent of SMX degradation by photolysis alone is $45 \%$ after $90 \mathrm{~min}$ and increases to $95 \%$ in the presence of photocatalyst. Notably, adsorption alone does not contribute to SMX removal. Several researchers have reported the existence of an optimum value for the modification of titanium dioxide from different metals. For example, Vargas et al. [34], who studied the UV-driven photocatalytic decomposition of the azo dye cibacron yellow over iron-doped titanium dioxide, reported that the best performance was achieved by the $0.5 \% \mathrm{Fe} / \mathrm{TiO}_{2}$ sample, while samples doped with higher levels of iron (i.e., $1 \%, 1.5 \%$ and $2 \%$ ) were less effective.

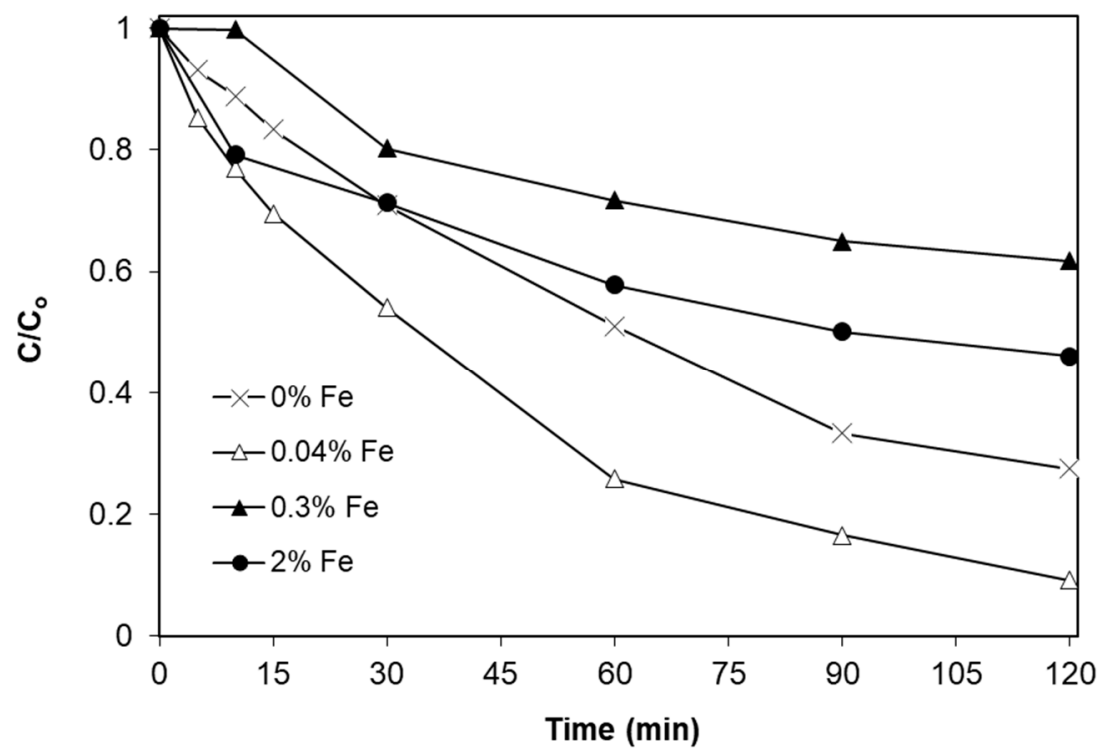

Figure 4. Effect of iron loading on the photocatalytic degradation of sulfamethoxazole (SMX) in ultrapure water $(\mathrm{UPW})$. $[\mathrm{SMX}]=234 \mu \mathrm{g} / \mathrm{L},\left[\mathrm{Fe} / \mathrm{TiO}_{2}\right]=1 \mathrm{~g} / \mathrm{L}$ and natural $\mathrm{pH}$.

However, they also reported that the undoped sample was more efficient than either of the doped ones in terms of mineralization. In other studies, $\mathrm{Li}$ et al. [35] examined the efficiency of $\mathrm{Fe} / \mathrm{TiO}_{2}$ aerogel for the degradation of cyclohexane in the presence of molecular oxygen. They found that a $\mathrm{Fe} / \mathrm{TiO}_{2}$ doping level between $0.5 \%$ and $1 \%$ was optimum for the destruction of cyclohexane under simulated solar radiation. Several researchers have demonstrated an optimum value for the deposition of metals on titania [36,37], while higher metal loadings may (i) increase the rate of the recombination between holes and electrons. When the dopant concentration becomes too high, many crystal defects could be induced, which may serve as recombination centers; and/or (ii) reduce the number of active sites on the surface of titania, thus leading to decreased efficiencies [34]. 


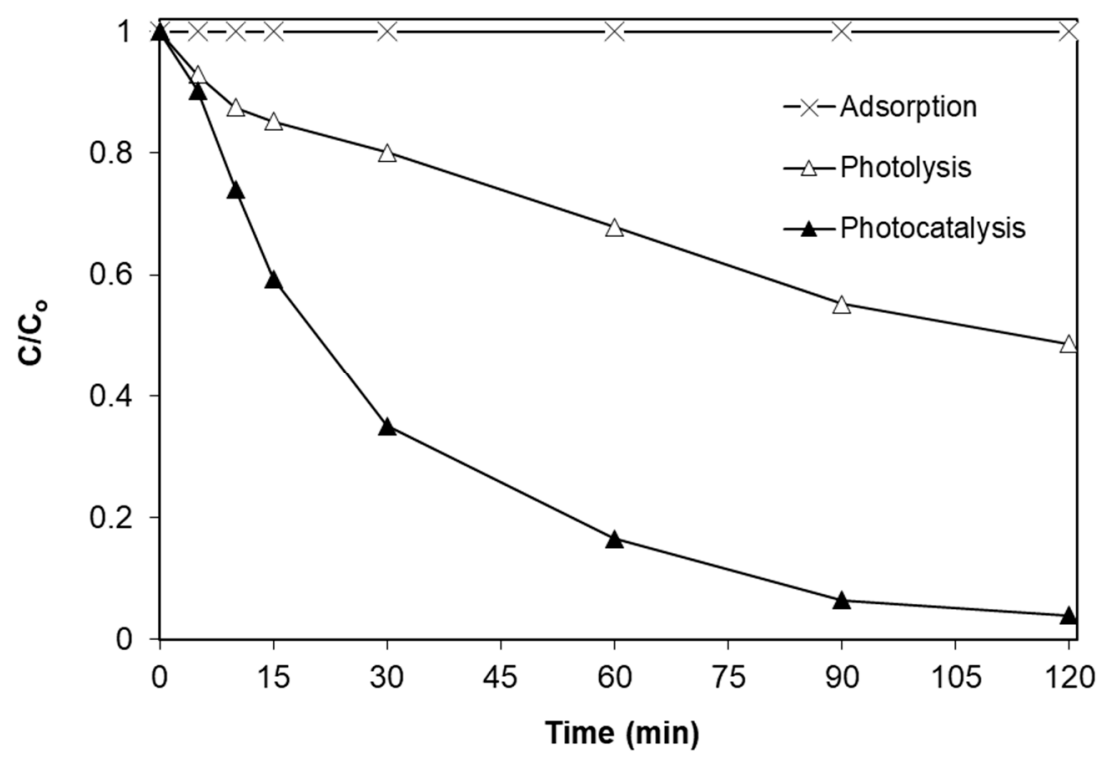

Figure 5. Adsorption, photolysis and photocatalytic degradation of SMX in UPW. [SMX] $=234 \mu \mathrm{g} / \mathrm{L}$, $\left[0.04 \% \mathrm{Fe} / \mathrm{TiO}_{2}\right]=1 \mathrm{~g} / \mathrm{L}$ and natural $\mathrm{pH}$.

It is worth noting that when the same set of iron-doped titania samples were employed for water disinfection under comparable conditions [29], the highest activity was achieved with the $2 \% \mathrm{Fe} / \mathrm{TiO}$ sample. This suggests that photocatalytic activity may be case-specific and depend on the selected probe/indicator species (i.e., microcontaminants, pathogens), as well as on treatment objectives (i.e., removal of target compound(s), mineralization, disinfection).

\subsection{Effect of Catalyst Loading}

The effect of catalyst loading on the photocatalytic destruction of $234 \mu \mathrm{g} / \mathrm{L} \mathrm{SMX}$ in ultrapure water was investigated and the results are presented in Figure 6; apparent kinetic constants shown in Figure $6 \mathrm{~b}$ are computed assuming a pseudo-first-order rate expression, i.e.,:

$$
\frac{d[\mathrm{SMX}]}{\mathrm{dt}}=-\mathrm{k}_{\mathrm{app}} c \Leftrightarrow \operatorname{Ln} \frac{C_{o}}{\mathrm{C}}=\mathrm{k}_{\mathrm{app}} t .
$$

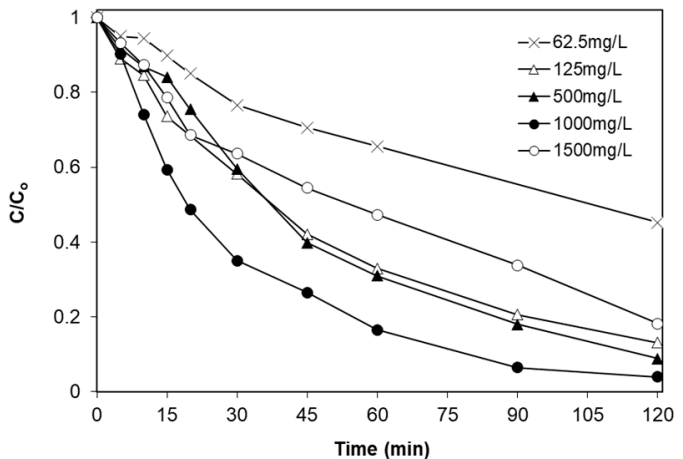

(a)

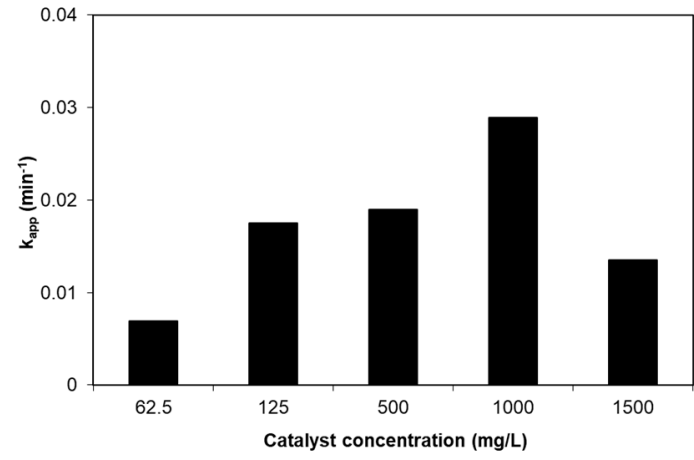

(b)

Figure 6. Effect of catalyst loading on the photocatalytic degradation of SMX in UPW (a) and apparent kinetic constants (b). [SMX] $=234 \mu \mathrm{g} / \mathrm{L}$ and natural $\mathrm{pH}$.

Increasing catalyst concentration up to $1 \mathrm{~g} / \mathrm{L}$ increases the SMX degradation rate, however, a further increase appears to have a detrimental effect. For example, when the concentration increases 
from $62.5 \mathrm{mg} / \mathrm{L}$ to $1 \mathrm{~g} / \mathrm{L}$, the apparent kinetic constant increases four-fold (i.e., from $7 \times 10^{-3}$ to $29 \times 10^{-3} \mathrm{~min}^{-1}$ ); the value drops by ca. $50 \%$ though (i.e., $13.5 \times 10^{-3} \mathrm{~min}^{-1}$ ) at $1.5 \mathrm{~g} / \mathrm{L}$ catalyst concentration. This behavior has been observed by several researchers for many types of reactors, as well as photocatalytic materials $[20,21]$ and it may be attributed to two opposing phenomena, i.e., (i) increased catalyst loadings correspond to more active catalytic centers and, therefore increased efficiency, but (ii) an excessive amount of catalyst clouds the solution and, therefore, less radiation is available to activate the catalyst (shading effect).

\subsection{Effect of Initial SMX Concentration}

A large variety of organic compounds are detected in environmental samples at different concentrations. It is, therefore, crucial to study the effect of the initial concentration of organic pollutant on its removal. Figure 7 shows the variation of normalized SMX concentration at four initial concentrations in the range $234-1404 \mu \mathrm{g} / \mathrm{L}$. As can be seen, the photocatalytic destruction of SMX does not follow a true first-order kinetic expression since the four curves do not overlap. This also is evident comparing the apparent rate constants, whose values decrease as the SMX concentration increases.

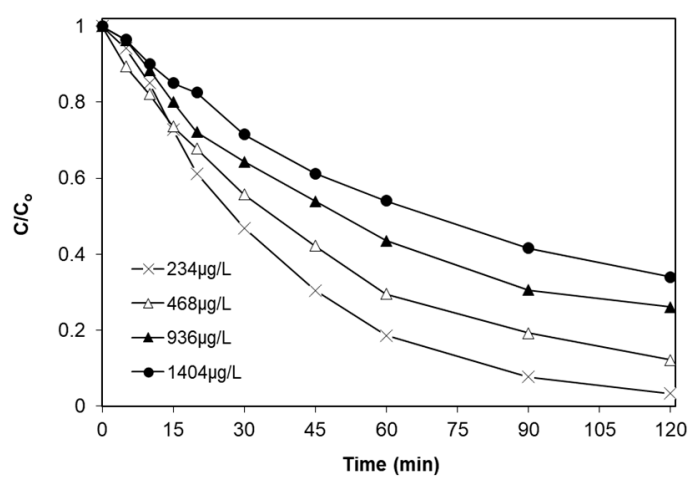

(a)

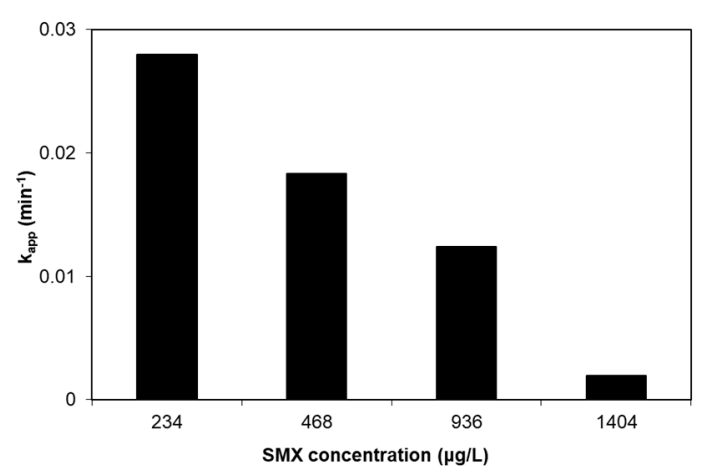

(b)

Figure 7. Effect of initial SMX concentration on its photocatalytic degradation in UPW (a) and apparent kinetic constants (b). $\left[0.04 \% \mathrm{Fe} / \mathrm{TiO}_{2}\right]=1 \mathrm{~g} / \mathrm{L}$ and natural $\mathrm{pH}$. Inset: Apparent kinetic constants.

It should be noted here that, although the rate is not pseudo-first-order, data fitting to Equation (1) is still good (i.e., the linear regression coefficients of the $\operatorname{Ln}(\mathrm{Co} / \mathrm{C})$ versus time plots are $>97.6 \%$ for the four curves). This kinetic behavior is common in photocatalytic systems [38], as well as in other advanced oxidation processes such as electrochemical oxidation, electro-Fenton [39] or sonodegradation [40]. The observed rate decrease with increasing substrate concentration may be ascribed to mass transport limitations, as well as to the fact that reactive oxygen species may become the limiting reactant.

\subsection{Effect of $\mathrm{pH}$ and the Water Matrix}

To study the effect of $\mathrm{pH}$ on SMX removal, experiments were performed at different initial $\mathrm{pH}$ values and the results are shown in Figure 8. Alkaline environments strongly hinder SMX decomposition, while acidic and natural $\mathrm{pH}$ (i.e., 5.4) conditions result in comparable rates. The effect of $\mathrm{pH}$ on the photocatalytic reaction may occur in different ways. Depending on the ionic strength, the adsorption of SMX on the catalyst surface may be favored. The catalyst is positively charged at values below the point of zero charge (6.2) and negatively charged at higher values. On the other hand, SMX at $\mathrm{pH}$ values below 1.85 is positively charged and above 5.6 is negatively charged, while between the two values it exists in its neutral form [41]. As $\mathrm{pH}$ increases, more hydroxyl radicals are likely to be produced due to the greater occurrence of hydroxyl ions. Therefore, both the contribution of electrostatic forces between SMX and the surface and the generation of oxidative species will dictate the degradation rate since both phenomena are $\mathrm{pH}$-sensitive. 


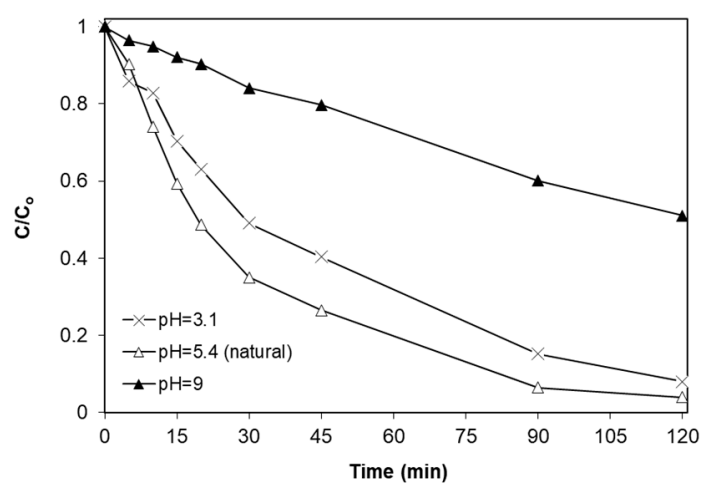

(a)

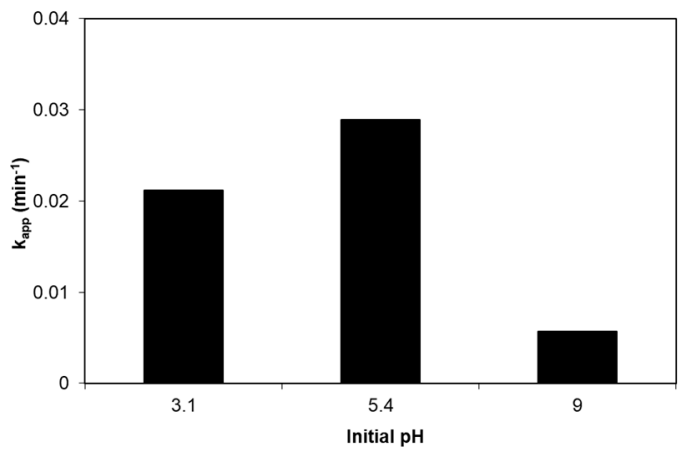

(b)

Figure 8. Effect of initial solution $\mathrm{pH}$ on the photocatalytic degradation of SMX in UPW (a) and apparent kinetic constants (b). $[\mathrm{SMX}]=234 \mu \mathrm{g} / \mathrm{L},\left[0.04 \% \mathrm{Fe} / \mathrm{TiO}_{2}\right]=1 \mathrm{~g} / \mathrm{L}$.

Additional experiments were performed in real water matrices such as bottled water (BW), river water (RW) and wastewater (WW) and the results are shown in Figure 9. Reactions in bottled water and river water are nearly as fast as in ultrapure water with the respective kinetic constants (Figure $9 \mathrm{~b}$ ) being $22.4 \times 10^{-3}, 23.6 \times 10^{-3}$ and $30 \times 10^{-3} \mathrm{~min}^{-1}$. On the contrary, SMX degradation is considerably impeded when the reaction takes place in secondary treated wastewater $\left(5 \times 10^{-3} \mathrm{~min}^{-1}\right)$ or wastewater diluted with an equal volume of ultrapure water $\left(8.5 \times 10^{-3} \mathrm{~min}^{-1}\right)$.

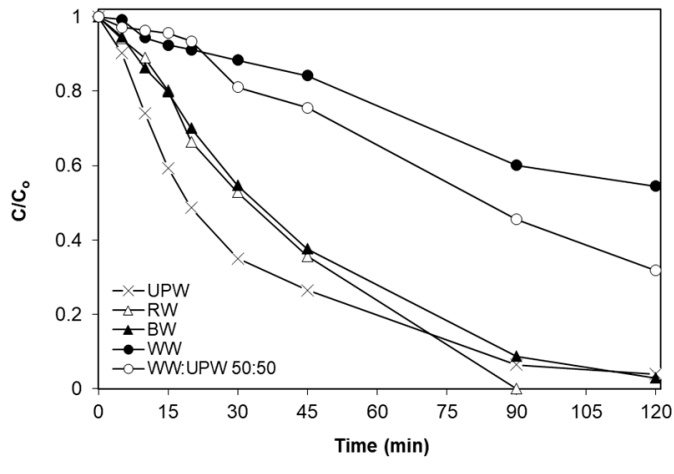

(a)

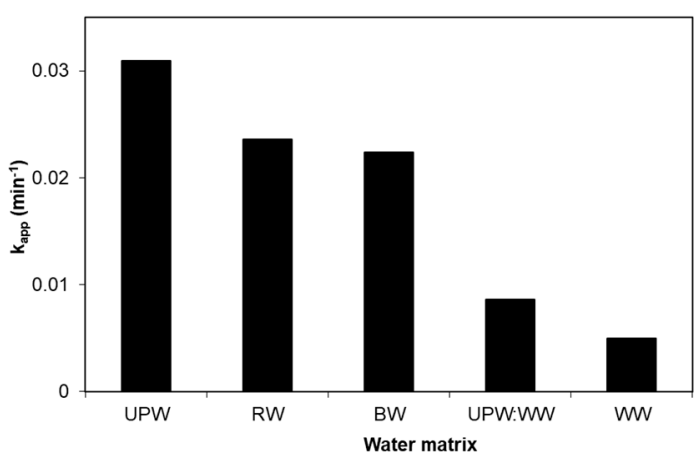

(b)

Figure 9. Effect of the water matrix on the photocatalytic degradation of SMX (a) and apparent kinetic constants (b). $[\mathrm{SMX}]=234 \mu \mathrm{g} / \mathrm{L},\left[0.04 \% \mathrm{Fe} / \mathrm{TiO}_{2}\right]=1 \mathrm{~g} / \mathrm{L}$ and natural $\mathrm{pH}$.

This is not surprising since several studies have reported a decrease in photocatalytic activity as a function of the water matrix complexity. Ioannidou et al. [21] observed that the degradation of SMX using a $\mathrm{WO}_{3} / \mathrm{TiO}_{2}$ composite catalyst was almost nine times slower in secondary effluent than in ultrapure water. Similar results have been reported by Choi et al. [42], who examined the photodegradation of SMX under UVA radiation using titania as the photocatalyst; they reported a rate decrease by ca. 10.5 times between the experiments conducted in ultrapure water and secondary effluent. In most cases, this negative effect is ascribed to the presence of non-target organic compounds and inorganic ions that compete with the pollutants for both the oxidants and the active sites of the catalyst [42].

\subsection{Effect of Humic Acid, Bicarbonate and Tert-Butanol}

In an effort to shed light on the factors influencing the performance in real water matrices, experiments were carried out in the presence of typical water constituents, such as bicarbonate and humic acid, as well as compounds that scavenge specific oxygen species, such as tert-butanol, added 
in ultrapure water; the results are shown in Figure 10. Humic acid (HA) is often used to simulate the organic matter present in both secondary wastewaters (effluent organic matter) and environmental samples (natural organic matter). The presence of $2-5 \mathrm{mg} / \mathrm{L}$ HA decreases the apparent kinetic constant by ca. seven times in comparison with ultrapure water (Figure 10a). This is probably due to the consumption of reactive oxygen species for the oxidation of humic acid. In addition, humic acid can act as a filter for the solar radiation, thus allowing less radiation to reach the catalyst and thereby leading to the production of fewer radicals. The kinetic constant appears to increase slightly at $10 \mathrm{mg} / \mathrm{L} \mathrm{HA}$; a possible explanation involves catalyst sensitization in the presence of humic acid or the production of additional oxidative species by the photolysis of HA [43].

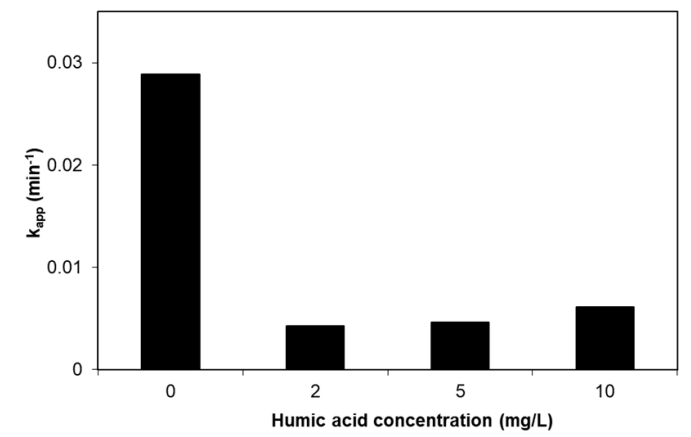

(a)

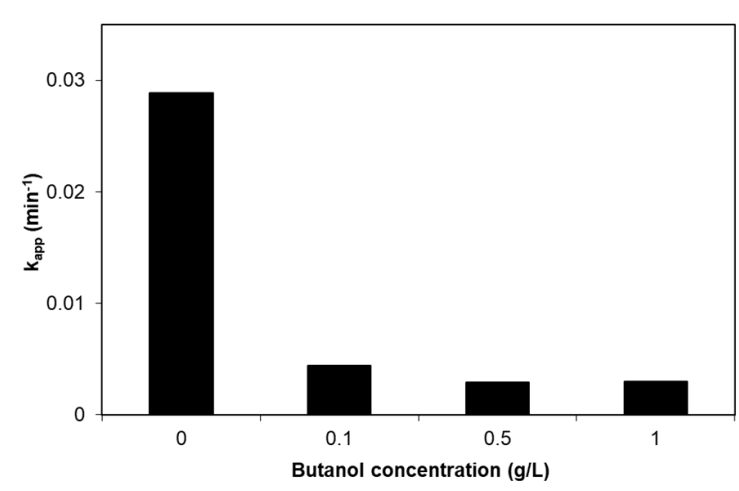

(c)

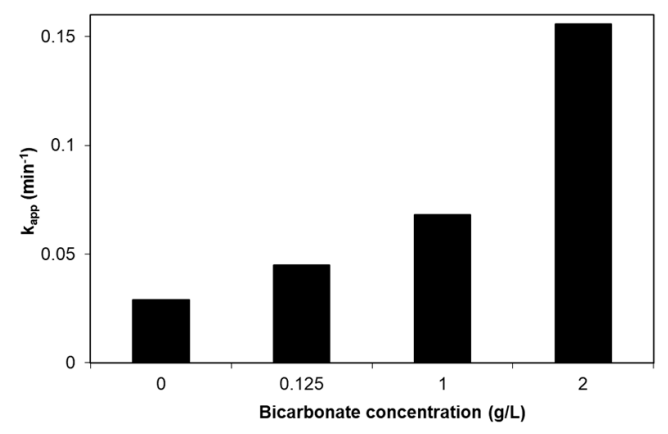

(b)

Figure 10. Effect of humic acid (a), bicarbonate (b), tert-butanol (c) on the photocatalytic degradation of SMX in UPW. [SMX] $=234 \mu \mathrm{g} / \mathrm{L},\left[0.04 \% \mathrm{Fe} / \mathrm{TiO}_{2}\right]=1 \mathrm{~g} / \mathrm{L}$ and natural $\mathrm{pH}$.

Bicarbonates are perhaps the most abundant inorganic ions present in environmental samples and are often accused of reducing photocatalytic activity [44]. This is because they react with hydroxyl radicals to form carbonate radicals that have lower oxidation potential $\left(\mathrm{E}_{\mathrm{o}}=1.78 \mathrm{~V}, \mathrm{pH}=7\right)$, as follows:

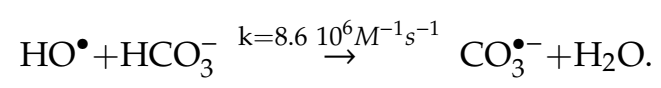

Interestingly, addition of bicarbonates in the range $125 \mathrm{mg} / \mathrm{L}$ to $2 \mathrm{~g} / \mathrm{L}$ favors SMX degradation, as can be seen in Figure 10b. Although carbonate radicals are weaker oxidizing agents than hydroxyl radicals, they have longer lifetime and, therefore, more chances to diffuse away from the catalyst surface and react with SMX in the interfacial region. Furthermore, carbonate radicals are more selective for electron-rich compounds than hydroxyl radicals [45]. The results of Figure 10b are consistent with those shown in Figure 9 concerning SMX degradation in bottled water, where bicarbonates are the dominant ions at $210 \mathrm{mg} / \mathrm{L}$ concentration [46]. It seems that other than bicarbonate ions (e.g. chloride, nitrate) may be responsible for the slightly reduced degradation rates recorded in natural waters. 
Additional experiments were performed in the presence of tert-butanol in the range $0.1-1 \mathrm{~g} / \mathrm{L}$ acting as possible scavenger of hydroxyl radicals with a second-order kinetic constant equal to $6 \times 10^{8} \mathrm{M}^{-1} \mathrm{~s}^{-1}$ [44]. Indeed, the presence of alcohol retards SMX degradation 7-10 times depending on its concentration (Figure 10c).

\subsection{Effect of Sodium Persulfate}

Another means to increase the efficiency of photocatalytic systems is the addition of electron acceptors, such as hydrogen peroxide or sodium persulfate (SPS). These oxidants may (i) trap the photogenerated electrons, thus impeding their reaction with valence band holes, and (ii) generate additional oxidizing species, such as sulfate radicals in the case of persulfate anion:

$$
\mathrm{e}^{-}+\mathrm{S}_{2} \mathrm{O}_{8}^{2-} \rightarrow \mathrm{SO}_{4}^{\bullet-}+\mathrm{SO}_{4}^{2-}
$$

As seen in Figure 11, addition of sodium persulfate at $100 \mathrm{mg} / \mathrm{L}$ nearly doubles the rate of SMX degradation, while a further increase to $150 \mathrm{mg} / \mathrm{L}$ has no additional effect; there are several reports explaining the existence of an optimum oxidant concentration, beyond which self-scavenging reactions may occur, as follows:

$$
\mathrm{SO}_{4}^{-\bullet}+\mathrm{S}_{2} \mathrm{O}_{8}^{2-} \rightarrow \mathrm{SO}_{4}^{2-}+\mathrm{S}_{2} \mathrm{O}_{8}^{\bullet-}
$$

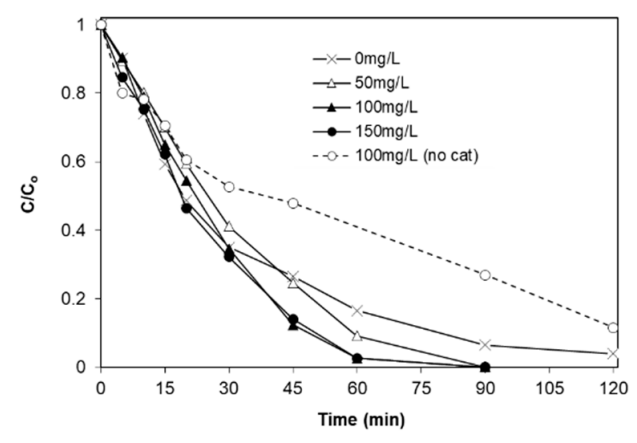

(a)

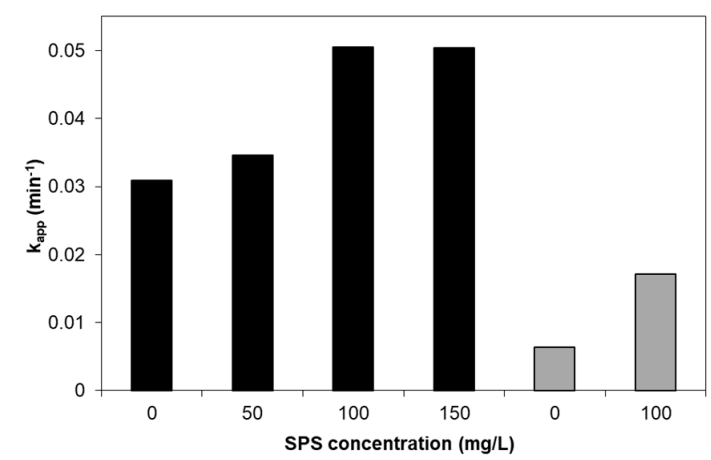

(b)

Figure 11. Effect of sodium persulfate on the photolytic and photocatalytic degradation of SMX in $\mathrm{UPW}(\mathbf{a})$ and apparent kinetic constants $(\mathbf{b}) .[\mathrm{SMX}]=234 \mu \mathrm{g} / \mathrm{L},\left[0.04 \% \mathrm{Fe} / \mathrm{TiO}_{2}\right]=1 \mathrm{~g} / \mathrm{L}$ and natural pH.

We have recently demonstrated [47] that the UVA fraction of solar radiation can activate persulfate and generate sulfate radicals according to the reaction:

$$
\mathrm{S}_{2} \mathrm{O}_{8}^{2-}+\mathrm{hv} \rightarrow 2 \mathrm{SO}_{4}^{-\bullet} .
$$

Moreover, Wang et al. [48] reported that persulfate could be activated under visible light and used for disinfection purposes. Under this perspective, an additional experiment was carried out with $100 \mathrm{mg} / \mathrm{L}$ SPS in the absence of photocatalyst (shown by the dotted line in Figure 11a; as can be seen in Figure $11 \mathrm{~b}$ (grey bars), the rate of SMX degradation by photolysis with SPS increases by as much as about three times compared to photolysis without SPS.

To evaluate whether coupling solar photocatalysis with light-induced SPS activation leads to synergistic effects, the degree of synergy, S, can be computed as follows [49]:

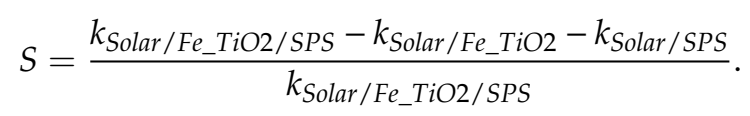

An $S$ value greater than zero indicates a synergistic effect, i.e., the rate of the combined process is actually greater than the sum of the rates of the individual processes, while a zero value indicates a 
cumulative effect where the two rates simply add up. Applying Equation (6) for the kinetic constants shown in Figure 11b, $\mathrm{S}$ is computed equal to $9 \%$, thus implying a minor synergistic effect.

\subsection{Catalyst Reuse}

Although a wide variety of photocatalytic materials responsive in the visible light exhibit excellent activity, they suffer from low stability [20]. To evaluate the reusability of the $0.04 \% \mathrm{Fe} / \mathrm{TiO}_{2}$ photocatalyst, five successive experiments were performed, as follows: The fresh catalyst at $1 \mathrm{~g} / \mathrm{L}$ was loaded in the reaction vessel and the solution was irradiated for $120 \mathrm{~min}$. Thereafter, the reaction mixture was added a fresh amount of SMX and it was left to react for another $120 \mathrm{~min}$. This procedure was repeated four times, i.e., a total of five experiments including the starting one, and the results are shown in Figure 12.

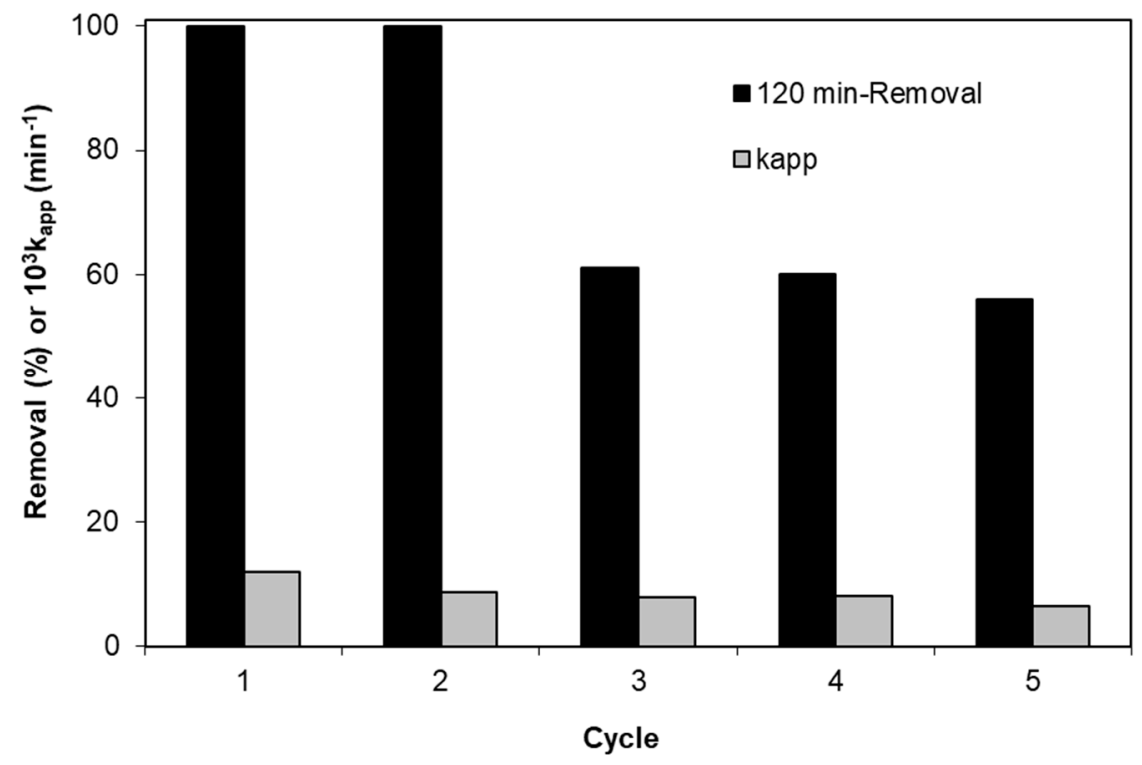

Figure 12. Catalyst reusability for SMX degradation in UPW. [SMX] $=117 \mu \mathrm{g} / \mathrm{L},\left[0.04 \% \mathrm{Fe} / \mathrm{TiO}_{2}\right]=1 \mathrm{~g} / \mathrm{L}$ and natural $\mathrm{pH}$.

Both the apparent kinetic constants (grey bars) and the 120-min conversion values (black bars) decreased by ca. $45 \%$ between the first and last experiments. A possible reason has to do with the accumulation of transformation by-products accompanying SMX degradation and their carrying-over between two consecutive experiments, since the rate of degradation seems to decrease with increasing organic content (i.e., Figures 7 and 10a,c).

\section{Materials and Methods}

\subsection{Catalyst Synthesis and Characterization}

A co-precipitation method was used for the preparation of Fe-doped titania samples with different molar ratios of iron in solutions, such as $0.04,0.3$ and $2 \mathrm{~mol} \%$. Iron-doped titania was precipitated at $\mathrm{pH} \sim 9$ from an aqueous solution of titanium (IV) oxysulfate by the addition of ammonia solution. After aging the suspension overnight, the precipitate was filtered and dried in air at $373 \mathrm{~K}$. The residue was crushed to a fine powder and annealed in a furnace at $973 \mathrm{~K}$ for $3 \mathrm{~h}$. The catalysts were crushed again and used further for characterization. Iron oxide was also prepared with the same method for comparison.

The crystal structure, particle size and morphology of Fe-doped materials were examined with powder X-ray diffraction system and scanning electron microscopy (SEM). Powder X-ray diffraction patterns were obtained on a Rigaku D/MAX-2000H rotating anode diffractometer (CuKa radiation, Rigaku Europe SE, Neu-Isenburg, Germany) equipped with the secondary pyrolytic graphite 
monochromator operated at $40 \mathrm{kV}$ and $80 \mathrm{~mA}$ through a scanning range from $2 \theta=10-80^{\circ}$ at a scan rate $0.02 \mathrm{~s}^{-1}$. The crystalline size was estimated using the Scherrer equation, while the lattice parameters were determined using Equation (7):

$$
\frac{1}{d_{(h k l)}^{2}}=\frac{h^{2}+k^{2}}{a^{2}}+\frac{l^{2}}{c^{2}} .
$$

where $h, k, l$ are the Miller indices and $a$ and $c$ are the lattice parameters (for a tetragonal structure, $\mathrm{a}=\mathrm{b} \neq \mathrm{c}$ ). The value of the lattice spacing $d_{(h k l)}$ for an XRD peak can be determined from Bragg's law, i.e.,:

$$
d_{(h k l)}=\frac{\lambda}{2 \sin \theta} .
$$

The UV-visible diffuse reflectance spectra were measured in the range $200-800 \mathrm{~nm}$ using a Perkin Elmer (LAMBDA 950 System, Perkin Elmer, Seer Green, UK) with $\mathrm{BaSO}_{4}$ as a reference standard. The band gaps were determined by plotting the Kubelka-Munk function. The surface morphology and elemental analysis were carried out using SEM and EDS spectroscopy on a JSM-6390LV instrument (JEOL, Peabody, MA, USA). Nanomaterials were dispersed on a sample holder, gold coated and viewed through an electron microscope.

\subsection{Chemicals}

Chemicals for the preparation of catalysts were purchased from Aldrich (Taufkirchen, Germany) and were of analytical reagent grade. Titanium (IV) oxysulfate hydrate $\left(\mathrm{TiOSO}_{4} \cdot \mathrm{xH}_{2} \mathrm{O}\right)$, iron (III) nitrate $\left(\mathrm{Fe}\left(\mathrm{NO}_{3}\right)_{3}\right)$ and ammonium hydroxide $\left(25 \% \mathrm{NH}_{4} \mathrm{OH}\right)$ were applied with no further purification. Sulfamethoxazole (SMX, $\mathrm{C}_{10} \mathrm{H}_{11} \mathrm{~N}_{3} \mathrm{O}_{3} \mathrm{~S}$, CAS number: 723-46-6), humic acid (HA, technical grade, CAS number: 1415-93-6), sodium bicarbonate (99\%, CAS number: 144-55-8), sodium hydroxide (98 wt.\%, CAS number: 1310-73-2) and sulfuric acid (95 wt.\%, CAS number: 7664-93-9) were purchased from Sigma-Aldrich. Acetonitrile (HPLC grade, CAS number: 75-05-8) was obtained from Panreac. Tert-butanol (99\%, CAS number: 75-65-0) was purchased from Fluka and sodium persulfate $(98 \%$, CAS number: 7775-27-1) was purchased from Acros Organics (Geel, Belgium).

\subsection{Photocatalytic Experiments}

The irradiation source was an Oriel LCS-100 solar simulator using a $100 \mathrm{~W}$ xenon, ozone-free lamp. The incident intensity was measured by actinometry and was found equal to $7.3 \times 10^{-7}$ einstein/(L.s). The reactor was a cylindrical vessel open to the atmosphere (open air equilibrium) with a useful volume of $120 \mathrm{~mL}$. In a typical run, SMX at an initial concentration in the range 117-1404 $\mu \mathrm{g} / \mathrm{L}$ was mixed with the appropriate amount of catalyst and left to equilibrate in the dark for $30 \mathrm{~min}$. Thereafter, the vessel was placed below the simulator to start the reaction. Sampling occurred at certain time intervals and samples were filtered to remove catalyst particles prior to analysis.

\subsection{High Performance Liquid Chromatography}

SMX concentration was measured using high performance liquid chromatography (Waters Alliance 2695, Hellamco SA, Athens, Greece) equipped with the 2996 photodiode array detector. More details can be found elsewhere [50].

\subsection{Water Matrices}

Although most of the experiments were conducted in ultrapure water (UPW, $\mathrm{pH}=6,0.056 \mu \mathrm{S} / \mathrm{cm}$ conductivity), other matrices were also tested as follows: (i) Secondary treated wastewater (WW, $\mathrm{pH}=8,7 \mathrm{mg} / \mathrm{L}$ total organic carbon (TOC), $1.1 \mathrm{mg} / \mathrm{L}$ total suspended solids, $21 \mathrm{mg} / \mathrm{L}$ chemical oxygen demand, $311 \mu \mathrm{S} / \mathrm{cm}$ conductivity, $30 \mathrm{mg} / \mathrm{L}$ sulfates, $0.44 \mathrm{mg} / \mathrm{L}$ chlorides), collected from the wastewater treatment plant of the University of Patras campus, Greece, (ii) commercially available bottled water 
(BW, $\mathrm{pH}=7.5,396 \mu \mathrm{S} / \mathrm{cm}$ conductivity, $211 \mathrm{mg} / \mathrm{L}$ bicarbonates, $15 \mathrm{mg} / \mathrm{L}$ sulfates, $9.8 \mathrm{mg} / \mathrm{L}$ chlorides), (iii) river water taken from the region of Athens, Greece ( $\mathrm{RW}, \mathrm{pH}=7.5,491 \mu \mathrm{S} / \mathrm{cm}$ conductivity, TOC $=2.7 \mathrm{mg} / \mathrm{L}, 274 \mathrm{mg} / \mathrm{L}$ sulfates, $5 \mathrm{mg} / \mathrm{L}$ chlorides).

\section{Conclusions}

The conclusions of this study can be summarized as follows:

- The degradation of SMX follows pseudo-first-order kinetics with the apparent kinetic constant decreasing with increasing initial SMX concentration. The reaction is favored at low levels of iron doping $(0.04 \%)$, increased catalyst concentrations (up to $1 \mathrm{~g} / \mathrm{L}$ ) and at the solution's inherent $\mathrm{pH}$.

- Complex water matrices such as secondary treated wastewaters considerably retard SMX degradation, and this may partly be associated with the presence of species, such as humic acid. Conversely, bicarbonate seems to have a positive effect.

- The presence of an electron acceptor (sodium persulfate) enhances SMX removal. The contribution of persulfate activation to the photocatalytic SMX degradation is additive rather than synergistic.

- Partial photocatalyst deactivation occurs after five successive experiments with the same catalyst sample.

- The same family of iron-doped titania samples was employed in our previous work [29] for the effective photocatalytic elimination of Staphylococcus aureus; the implications for water/wastewater treatment are encouraging since modified titania can exploit solar light for the combined decontamination and disinfection of polluted waters.

Author Contributions: Investigation, A.T. and V.B.; Methodology, Z.F. and D.M.; Resources, V.B.; Supervision, Z.F., G.K. and D.M.

Funding: Part of this work was financially supported by the Stavros Niarchos Foundation within the framework of the project ARCHERS (Advancing Young Researchers' Human Capital in Cutting Edge Technologies in the Preservation of Cultural Heritage and the Tackling of Societal Challenges).

Conflicts of Interest: The authors declare no conflict of interest.

\section{References}

1. Aminov, R.I. A Brief History of the Antibiotic Era: Lessons Learned and Challenges for the Future. Front. Microbiol. 2010, 1, 134. [CrossRef] [PubMed]

2. Fischbach, M.A.; Walsh, C.T. Antibiotics for emerging pathogens. Science 2009, 325, 1089-1093. [CrossRef] [PubMed]

3. Rivera-Jaimes, J.A.; Postigo, C.; Melgoza-Alemán, R.M.; Aceña, J.; Barceló, D.; López de Alda, M. Study of pharmaceuticals in surface and wastewater from Cuernavaca, Morelos, Mexico: Occurrence and environmental risk assessment. Sci. Total Environ. 2018, 613-614, 1263-1274. [CrossRef] [PubMed]

4. Patel, M.; Kumar, R.; Kishor, K.; Mlsna, T.; Pittman, C.U.; Mohan, D. Pharmaceuticals of Emerging Concern in Aquatic Systems: Chemistry, Occurrence, Effects, and Removal Methods. Chem. Rev. 2019, 119, 3510-3673. [CrossRef] [PubMed]

5. Quesada, H.B.; Baptista, A.T.A.; Cusioli, L.F.; Seibert, D.; Bezerra, C.D.O.; Bergamasco, R. Surface water pollution by pharmaceuticals and an alternative of removal by low-cost adsorbents: A review. Chemosphere 2019, 222, 766-780. [CrossRef] [PubMed]

6. White, D.; Lapworth, D.J.; Civil, W.; Williams, P. Tracking changes in the occurrence and source of pharmaceuticals within the River Thames, UK; from source to sea. Environ. Pollut. 2019, 249, $257-266$. [CrossRef] [PubMed]

7. Su, T.; Deng, H.; Benskin, J.P.; Radke, M. Biodegradation of sulfamethoxazole photo-transformation products in a water/sediment test. Chemosphere 2016, 148, 518-525. [CrossRef]

8. Barnes, K.K.; Kolpin, D.W.; Furlong, E.T.; Zaugg, S.D.; Meyer, M.T.; Barber, L.B. A national reconnaissance of pharmaceuticals and other organic wastewater contaminants in the United States-I) Groundwater. Sci. Total Environ. 2008, 402, 192-200. [CrossRef] [PubMed] 
9. Batt, A.L.; Kim, S.; Aga, D.S. Comparison of the occurrence of antibiotics in four full-scale wastewater treatment plants with varying designs and operations. Chemosphere 2007, 68, 428-435. [CrossRef]

10. Rizzo, L.; Manaia, C.; Merlin, C.; Schwartz, T.; Dagot, C.; Ploy, M.; Michael, I.; Fatta-Kassinos, D. Urban wastewater treatment plants as hotspots for antibiotic resistant bacteria and genes spread into the environment: A review. Sci. Total Environ. 2013, 447, 345-360. [CrossRef]

11. Zhang, Y.; Zhuang, Y.; Geng, J.; Ren, H.; Xu, K.; Ding, L. Reduction of antibiotic resistance genes in municipal wastewater effluent by advanced oxidation processes. Sci. Total Environ. 2016, 550, 184-191. [CrossRef]

12. Dantas, R.F.; Contreras, S.; Sans, C.; Esplugas, S. Sulfamethoxazole abatement by means of ozonation. J. Hazard. Mater. 2008, 150, 790-794. [CrossRef]

13. Boudreau, J.; Bejan, D.; Li, S.; Bunce, N.J. Competition between Electrochemical Advanced Oxidation and Electrochemical Hypochlorination of Sulfamethoxazole at a Boron-Doped Diamond Anode. Ind. Eng. Chem. Res. 2010, 49, 2537-2542. [CrossRef]

14. Ribeiro, R.S.; Frontistis, Z.; Mantzavinos, D.; Venieri, D.; Antonopoulou, M.; Konstantinou, I.; Silva, A.M.; Faria, J.L.; Gomes, H.T. Magnetic carbon xerogels for the catalytic wet peroxide oxidation of sulfamethoxazole in environmentally relevant water matrices. Appl. Catal. B Environ. 2016, 199, 170-186. [CrossRef]

15. Wang, S.; Wang, J. Comparative study on sulfamethoxazole degradation by Fenton and Fe(ii)-activated persulfate process. RSC Adv. 2017, 7, 48670-48677. [CrossRef]

16. Kemmou, L.; Frontistis, Z.; Vakros, J.; Manariotis, I.D.; Mantzavinos, D. Degradation of antibiotic sulfamethoxazole by biochar-activated persulfate: Factors affecting the activation and degradation processes. Catal. Today 2018, 313, 128-133. [CrossRef]

17. Al-Hamadani, Y.A.; Chu, K.H.; Flora, J.R.; Kim, D.-H.; Jang, M.; Sohn, J.; Joo, W.; Yoon, Y. Sonocatalytical degradation enhancement for ibuprofen and sulfamethoxazole in the presence of glass beads and single-walled carbon nanotubes. Ultrason. Sonochem. 2016, 32, 440-448. [CrossRef]

18. Yang, Y.; Lu, X.; Jiang, J.; Ma, J.; Liu, G.; Cao, Y.; Liu, W.; Li, J.; Pang, S.; Kong, X.; et al. Degradation of sulfamethoxazole by $\mathrm{UV}, \mathrm{UV} / \mathrm{H}_{2} \mathrm{O}_{2}$ and $\mathrm{UV} /$ persulfate (PDS): Formation of oxidation products and effect of bicarbonate. Water Res. 2017, 118, 196-207. [CrossRef]

19. Mirzaei, A.; Yerushalmi, L.; Chen, Z.; Haghighat, F.; Guo, J. Enhanced photocatalytic degradation of sulfamethoxazole by zinc oxide photocatalyst in the presence of fluoride ions: Optimization of parameters and toxicological evaluation. Water Res. 2018, 132, 241-251. [CrossRef]

20. Grilla, E.; Petala, A.; Frontistis, Z.; Konstantinou, I.K.; Kondarides, D.I.; Mantzavinos, D. Solar photocatalytic abatement of sulfamethoxazole over $\mathrm{Ag}_{3} \mathrm{PO}_{4} / \mathrm{WO}_{3}$ composites. Appl. Catal. B Environ. 2018, 231, $73-81$. [CrossRef]

21. Ioannidou, E.; Frontistis, Z.; Antonopoulou, M.; Venieri, D.; Konstantinou, I.; Kondarides, D.I.; Mantzavinos, D. Solar photocatalytic degradation of sulfamethoxazole over tungsten-Modified $\mathrm{TiO}_{2}$. Chem. Eng. J. 2017, 318, 143-152. [CrossRef]

22. Długosz, M.; Żmudzki, P.; Kwiecień, A.; Szczubiałka, K.; Krzek, J.; Nowakowska, M. Photocatalytic degradation of sulfamethoxazole in aqueous solution using a floating $\mathrm{TiO}_{2}$-expanded perlite photocatalyst. J. Hazard. Mater. 2015, 298, 146-153.

23. Bhatkhande, D.S.; Pangarkar, V.G.; Beenackers, A.A. Photocatalytic degradation for environmental applications-A review. J. Chem. Technol. Biotechnol. 2002, 77, 102-116. [CrossRef]

24. Braham, R.J.; Harris, A.T. Review of Major Design and Scale-up Considerations for Solar Photocatalytic Reactors. Ind. Eng. Chem. Res. 2009, 48, 8890-8905. [CrossRef]

25. Pelaez, M.; Nolan, N.T.; Pillai, S.C.; Seery, M.K.; Falaras, P.; Kontos, A.G.; Dunlop, P.S.; Hamilton, J.W.; Byrne, J.; O'Shea, K.; et al. A review on the visible light active titanium dioxide photocatalysts for environmental applications. Appl. Catal. B Environ. 2012, 125, 331-349. [CrossRef]

26. Liu, B.; Fang, Y.; Li, Z.; Xu, S. Visible-Light Nanostructured Photocatalysts-A Review. J. Nanosci. Nanotechnol. 2015, 15, 889-920. [CrossRef]

27. Petala, A.; Noe, A.; Frontistis, Z.; Drivas, C.; Kennou, S.; Mantzavinos, D.; Kondarides, D.I. Synthesis and characterization of $\mathrm{CoOx} / \mathrm{BiVO}_{4}$ photocatalysts for the degradation of propyl paraben. J. Hazard. Mater. 2019, 372, 52-60. [CrossRef]

28. Repousi, V.; Petala, A.; Frontistis, Z.; Antonopoulou, M.; Konstantinou, I.; Kondarides, D.I.; Mantzavinos, D. Photocatalytic degradation of bisphenol A over $\mathrm{Rh} / \mathrm{TiO}_{2}$ suspensions in different water matrices. Catal. Today 2017, 284, 59-66. [CrossRef] 
29. Venieri, D.; Tournas, F.; Gounaki, I.; Binas, V.; Zachopoulos, A.; Kiriakidis, G.; Mantzavinos, D. Inactivation of Staphylococcus aureus in water by means of solar photocatalysis using metal doped $\mathrm{TiO}_{2}$ semiconductors. J. Chem. Technol. Biotechnol. 2017, 92, 43-51. [CrossRef]

30. Majeed Khan, M.A.; Siwach, R.; Kumar, S.; Alhazaa, A.N. Role of Fe doping in tuning photocatalytic and photoelectrochemical properties of $\mathrm{TiO}_{2}$ for photodegradation of methylene blue. Opt. Laser Technol. 2019, 118, 170-178. [CrossRef]

31. Moradi, V.; Ahmed, F.; Jun, M.B.G.; Blackburn, A.; Herring, R.A. Acid-treated Fe-doped TiO 2 as a high performance photocatalyst used for degradation of phenol under visible light irradiation. J. Environ. Sci. 2019, 83, 183-194. [CrossRef]

32. Crişan, M.; Mardare, D.; Ianculescu, A.; DrĂgan, N.; Nitoi, I.; Crişan, D.; Voicescu, M.; Todan, L.; Oancea, P.; Adomnitei, C.; et al. Iron doped $\mathrm{TiO}_{2}$ films and their photoactivity in nitrobenzene removal from water. Appl. Surf. Sci. 2018, 455, 201-215. [CrossRef]

33. Shi, X.; Zhang, Y.; Liu, X.; Jin, H.; Lv, H.; He, S.; Hao, H.; Li, C. A Mild in-Situ Method to Construct Fe-Doped Cauliflower-Like Rutile $\mathrm{TiO}_{2}$ Photocatalysts for Degradation of Organic Dye in Wastewater. Catalysts 2019, 9, 426. [CrossRef]

34. Vargas, X.; Tauchert, E.; Marin, J.-M.; Restrepo, G.; Dillert, R.; Bahnemann, D. Fe-doped titanium dioxide synthesized: Photocatalytic activity and mineralization study for azo dye. J. Photochem. Photobiol. A Chem. 2012, 243, 17-22. [CrossRef]

35. Li, X.; Yue, P.-L.; Kutal, C. Synthesis and photocatalytic oxidation properties of iron doped titanium dioxide nanosemiconductor particles. New J. Chem. 2003, 27, 1264. [CrossRef]

36. Daskalaki, V.M.; Kondarides, D.I. Efficient production of hydrogen by photo-induced reforming of glycerol at ambient conditions. Catal. Today 2009, 144, 75-80. [CrossRef]

37. Carp, O.; Huisman, C.; Reller, A. Photoinduced reactivity of titanium dioxide. Prog. Solid State Chem. 2004, 32, 33-177. [CrossRef]

38. Dimitrakopoulou, D.; Rethemiotaki, I.; Frontistis, Z.; Xekoukoulotakis, N.P.; Venieri, D.; Mantzavinos, D. Degradation, mineralization and antibiotic inactivation of amoxicillin by $\mathrm{UV}-\mathrm{A} / \mathrm{TiO}_{2}$ photocatalysis. J. Environ. Manag. 2012, 98, 168-174. [CrossRef]

39. Dirany, A.; Sirés, I.; Oturan, N.; Oturan, M.A. Electrochemical abatement of the antibiotic sulfamethoxazole from water. Chemosphere 2010, 81, 594-602. [CrossRef]

40. Safari, G.H.; Nasseri, S.; Mahvi, A.H.; Yaghmaeian, K.; Nabizadeh, R.; Alimohammadi, M. Optimization of sonochemical degradation of tetracycline in aqueous solution using sono-activated persulfate process. J. Environ. Health Sci. Eng. 2015, 13, 24. [CrossRef]

41. Xekoukoulotakis, N.P.; Drosou, C.; Brebou, C.; Chatzisymeon, E.; Hapeshi, E.; Fatta-Kassinos, D.; Mantzavinos, D. Kinetics of UV-A/TiO 2 photocatalytic degradation and mineralization of the antibiotic sulfamethoxazole in aqueous matrices. Catal. Today 2011, 161, 163-168. [CrossRef]

42. Choi, J.; Lee, H.; Choi, Y.; Kim, S.; Lee, S.; Lee, S.; Choi, W.; Lee, J. Heterogeneous photocatalytic treatment of pharmaceutical micropollutants: Effects of wastewater effluent matrix and catalyst modifications. Appl. Catal. B Environ. 2014, 147, 8-16. [CrossRef]

43. Xu, H.; Cooper, W.J.; Jung, J.; Song, W. Photosensitized degradation of amoxicillin in natural organic matter isolate solutions. Water Res. 2011, 45, 632-638. [CrossRef]

44. Stefan, M.I. Advanced Oxidation Processes for Water Treatment: Fundamentals and Applications; IWA Publishing: London, UK, 2017.

45. Chen, S.-N.; Hoffman, M.Z.; Parsons, G.H. Reactivity of the carbonate radical toward aromatic compounds in aqueous solution. J. Phys. Chem. 1975, 79, 1911-1912. [CrossRef]

46. Metheniti, M.E.; Frontistis, Z.; Ribeiro, R.S.; Silva, A.M.T.; Faria, J.L.; Gomes, H.T.; Mantzavinos, D. Degradation of propyl paraben by activated persulfate using iron-containing magnetic carbon xerogels: Investigation of water matrix and process synergy effects. Environ. Sci. Pollut. Res. 2018, 25, 34801-34810. [CrossRef]

47. Ioannidi, A.; Frontistis, Z.; Mantzavinos, D. Destruction of propyl paraben by persulfate activated with UV-A light emitting diodes. J. Environ. Chem. Eng. 2018, 6, 2992-2997. [CrossRef]

48. Wang, W.; Wang, H.; Li, G.; An, T.; Zhao, H.; Wong, P.K. Catalyst-free activation of persulfate by visible light for water disinfection: Efficiency and mechanisms. Water Res. 2019, 157, 106-118. [CrossRef] 
49. Frontistis, Z.; Mantzavinos, D. Chapter 11: Advanced oxidation processes for wastewater treatment. In Wastewater and Biosolids Management, 1st ed.; Kalavrouziotis, I., Ed.; IWA Publishing: London, UK, 2017.

50. Özkal, C.B.; Frontistis, Z.; Antonopoulou, M.; Konstantinou, I.; Mantzavinos, D.; Meriç, S. Removal of antibiotics in a parallel-plate thin-film-photocatalytic reactor: Process modeling and evolution of transformation by-products and toxicity. J. Environ. Sci. 2017, 60, 114-122. [CrossRef]

(C) 2019 by the authors. Licensee MDPI, Basel, Switzerland. This article is an open access article distributed under the terms and conditions of the Creative Commons Attribution (CC BY) license (http://creativecommons.org/licenses/by/4.0/). 